\title{
Effects of non-genetically and genetically modified organism (maize-soybean) diet on growth performance, nutrient digestibility, carcass weight, and meat quality of broiler chicken
}

\author{
Song Zhang ${ }^{1,2}$, Xiang $\mathrm{Ao}^{1}$, and In Ho $\mathrm{Kim}^{1, *}$
}

\begin{abstract}
* Corresponding Author: In Ho Kim Tel: +82-41-550-3652, Fax: +82-41-565-2949,

E-mail: inhokim@dankook.ac.kr
\end{abstract}

'Department of Animal Resource and Science, Dankook University, Cheonan 31116, Korea

2 Kemin Industries (Zhuhai) Co., Ltd. Sanzao, Zhuhai 519040, China

ORCID

Song Zhang

https://orcid.org/0000-0003-0570-1909 Xiang Ao

https://orcid.org/0000-0001-8851-7706

In Ho Kim

https://orcid.org/0000-0002-8785-6201

Submitted Sept 25, 2018; Revised Nov 1, 2018; Accepted Dec 6, 2018
Objective: This study was conducted to compare growth performance, nutrient digestibility and meat quality of broilers fed a genetically modified organism (GMO) diet or a non-GMO diet.

Methods: A total of 840 broilers with an initial body weight of $43.03 \mathrm{~g}$ per chick were randomly allocated into 1 of the following 2 dietary treatments lasted for 32 days ( 15 broilers per pen with 28 replicates per treatment): i) Trt 1, GMO maize-soybean meal based diet; ii) Trt 2, non-GMO maize soybean meal based diet. Both diets were maize-soybean meal diets. The GMO qualitative analysis, proximate analysis and amino acid analysis of the feed ingredient samples were carried out. Diets were formulated based on a nutrient matrix derived from analysis results. Growth performance was measured on day $0,7,17$, and 32 . And all other response criteria were measured on day 32 .

Results: The analysis results showed that the total Lys, Met, Thr of non-GMO grains were lower than that of GMO grains, the protein content of GMO soybean meal was higher than that of non-GMO soybean meal. Feed intake and feed conversion rate (FCR) were greater $(\mathrm{p}<0.05)$ in broilers provided with non-GMO diet than that of the GMO group from $\mathrm{d} 17$ to 32. A decrease in FCR was observed in birds fed the GMO diet through the entire experiment $(p<0.05)$. No significant impacts on blood profile, meat quality and nutrient digestibility were found in response to dietary treatments throughout the experimental period $(\mathrm{p}>0.05)$.

Conclusion: These results indicated that non-GMO diet showed a negative effect on growth performance but nutrient digestibility, blood profile, carcass weight and meat quality were not affected by non-GMO diets.

Keywords: Non-GMO Diet; GMO Diet; Growth Performance; Nutrient Digestibility; Broiler

\section{INTRODUCTION}

In 2018, genetically modified organism (GMO) crops have been commercialized for 23 years. From 1996 to 2015, the cumulative area of transgenic crops reached 2 billion hectares worldwide. The first experiment on feeds with a genetically modified ingredient was published by Hammond et al [1]. Even though the United Nations, World Health Organization (WHO), Food and Agriculture Organization (FAO), the US Food and Drug Administration (FDA) and Environmental Protection Agency (EPA) have all stated that DNA, including DNA from transgenic crops, is a safe, natural component of food [2-6], concerns of the safety of genetically modified grains have been continuous. The public is concerned with the outcomes of technical risk assessments. They are also troubled about the uncertainty related to these outcomes, suspecting that risk assessments are based on an insufficient level of scientific knowledge $[7,8]$. Consequently, the risk assessments currently conducted especially may be not able to 
address long term effects of genetically modified foods. Ethical concerns are also important, for example, that a particular technology is in some way "tampering with nature" or that unintended effects are unpredictable and thus unknown to science [9].

In a democratic society where choice exists, people have rights to consume food that they believe to be safe. Since there is a certain need for non-GMO food including non-GMO animal protein, we need effective systems to assess non-GMO in feedstuffs from the nutritional point of view. In 2004, an animal feeding trial demonstrated that N7070bt maize diets supported broiler growth with mortality and feed conversion rate (FCR) similar to that supported by the N7070 isoline control [10]. In the same year, Kan et al [11] reported the GMO soybean containing gene bt-CrylAc protein was nutritionally equivalent to non-GMO soybean varieties when fed to broilers. However, with the rapid development of breeding and biomolecular technology, it is difficult to avoid GMO ingredients in animal nutrition research. When our experts determined databases of raw materials or recommendations of animal nutritional needs, the GMO and non-GMO ingredients were not considered respectively. Recently, our nutritionists may be better at using GMO-ingredient to formulate diet than nonGMO. Or, it seems easier for animal nutritionists to make use of GMO diets comparing to non-GMO diets. During the past 10 years no experiments were conducted to determine the effects of an absolute non-GMO diet on animals. Consequently, the objective of the study is to compare growth performance, nutrient digestibility and meat quality of broiler fed either a GMO diet or a non-GMO diet.

\section{MATERIALS AND METHODS}

\section{Test and control corn and soybean meal}

GMO and non-GMO maize and soybean samples were sent to independent laboratory Kogenebiotech Co., LTD (Seoul, Korea) for GMO analysis. GMO qualitative analysis of maize was performed by polymerase chain reaction (PCR) with the specific primer pairs for SSIIb (reference gene), 35S Promoter, NOS Terminator, DP-098140-6, and DAS-40278-9 genes respectively. GMO qualitative analysis of soybean was performed by PCR with the specific primer pairs for Lectin (reference gene), 35S Promoter, NOS Terminator, MON89788, DP3054231, DO356043-5, MON87701, CV127, MON87708, MON87769, and DAS-68416-4 genes respectively. The results are shown in Table 1 and 2 . The results confirmed that the maize and soybean meal were non-GMO.

\section{Corn and soybean meal analysis}

Samples of each of the four lots of ingredients were used to carry out proximate analysis [12]. All raw materials formulated (non-GMO and GMO maize and soybean) in diet were pro-
Table 1. Qualitative analysis of genetically modified maize

\begin{tabular}{|c|c|}
\hline Analysis item $^{1)}$ & Non-maize \\
\hline SSIIb & Detected \\
\hline $35 S$ Promoter & Not detected \\
\hline NOS Terminator & Not detected \\
\hline DP-098140-6 & Not detected \\
\hline DAS40278-9 & Not detected \\
\hline
\end{tabular}

${ }^{1)}$ Independent laboratory Kogenebiotech Co. LTD reported.

vided by Daehan feed mill company which were imported from USA. Amino acid contents were determined, following acid hydrolysis with $6 \mathrm{~N} \mathrm{HCl}$ at $110^{\circ} \mathrm{C}$ for $24 \mathrm{~h}$, using an amino acid analyzer (Biochrom 20, Pharmacia Biotech, Cambridge, England) (Table 3).

\section{Animal, diet, experimental design}

A total of 840 male Ross 308 two-day-old (body weight [BW] of $43.03 \pm 5 \mathrm{~g}$ ) broiler chicks were obtained from a commercial hatchery (Yang Ji Company, Cheonan, Korea). All birds were randomly assigned into 2 dietary treatment groups by BW in a randomized complete block design. Each treatment had 28 replicate pens of 15 broilers in each pen. i) Trt 1, GMO maizesoybean meal based diet; ii) Trt 2, non-GMO maize soybean meal based diet. Both diets were maize-soybean meal diets. All birds were kept in stainless steel pens of identical size (1.75x $1.55 \mathrm{~m}$ ) in a house with concrete floors covered with clean rice bran in an area that was provided with continuous light and were given free access to water and mash feed. During the experiment, house's temperature was regulated around $32^{\circ} \mathrm{C}$. All diets were formulated to contain approximately equal amounts of the 3 first limiting dietary essential amino acids (methionine, cystine, and lysine), $\mathrm{Ca}$, absorbable $\mathrm{P}$, and $\mathrm{Na}$, based on the analytical data from the feedstuffs. All diets were formulated to meet or exceed the NRC [13] requirements for broilers. Chromium contents were 330 and $320 \mu \mathrm{g} / \mathrm{kg}$ in starter and finisher diets, respectively, as measured by atomic absorption

Table 2. Qualitative analysis of genetically modified soybean meal

\begin{tabular}{ll}
\hline Analysis item $^{1)}$ & Non-soybean meal \\
\hline Soybean reference gene (lectin) & Detected \\
35S Promoter & Not detected \\
NOS Terminator & Not detected \\
MON89788 & Not detected \\
DP305423-1 & Not detected \\
D0356043-5 & Not detected \\
MON87701 & Not detected \\
CV127 & Not detected \\
MON87708 & Not detected \\
MON87769 & Not detected \\
DAS-68416-4 & Not detected \\
\hline
\end{tabular}

${ }^{1)}$ Independent laboratory Kogenebiotech Co. LTD reported. 
Table 3. Compositions of corn and soybean meal sample

\begin{tabular}{|c|c|c|c|c|}
\hline \multirow{2}{*}{ Analyses ${ }^{1)}$} & \multicolumn{2}{|c|}{ Maize } & \multicolumn{2}{|c|}{ Soybean meal } \\
\hline & Non-GMO & GMO & Non-GMO & GMO \\
\hline \multicolumn{5}{|c|}{ Proximate analyses (\%) } \\
\hline Moisture & 12.3 & 12.1 & 11.5 & 11.6 \\
\hline Crude fat & 3.26 & 3.82 & 1.37 & 1.72 \\
\hline Crude protein & 8.03 & 7.86 & 45.89 & 46.3 \\
\hline Crude fibre & 2.43 & 1.67 & 6.53 & 3.51 \\
\hline \multicolumn{5}{|l|}{ Amino acids (\%) } \\
\hline Lys & 0.21 & 0.23 & 2.75 & 2.81 \\
\hline Met & 0.14 & 0.16 & 0.51 & 0.59 \\
\hline Cys & 0.15 & 0.17 & 0.65 & 0.68 \\
\hline Thr & 0.27 & 0.27 & 1.79 & 1.84 \\
\hline Val & 0.31 & 0.36 & 2.06 & 2.10 \\
\hline lle & 0.21 & 0.26 & 2.01 & 1.98 \\
\hline Leu & 0.84 & 0.91 & 3.46 & 3.43 \\
\hline Phe & 0.36 & 0.36 & 2.30 & 2.28 \\
\hline His & 0.22 & 0.23 & 1.28 & 1.26 \\
\hline Arg & 0.33 & 0.36 & 3.32 & 3.23 \\
\hline Pro & 0.54 & 0.68 & 1.76 & 1.93 \\
\hline Asp & 0.48 & 0.50 & 5.48 & 5.38 \\
\hline Ser & 0.37 & 0.36 & 2.30 & 2.35 \\
\hline Glu & 1.33 & 1.36 & 8.27 & 8.30 \\
\hline Gly & 0.28 & 0.29 & 2.00 & 1.94 \\
\hline Ala & 0.51 & 0.56 & 1.85 & 1.95 \\
\hline
\end{tabular}

1) Reported on an as-is basis.

spectrophotometer (Analyst 100, Perkin-Elmer, Norwalk, CT, USA). The initial and final diet compositions are shown in Table 4. All birds used in this trial were handled in accordance with the guidelines set forth by the Animal Care and Use Committee of Dankook University.

\section{Sampling and measurements}

The broilers were weighed by pen and feed intake (FI) was recorded on $\mathrm{d} 0,7,17$, and 32 . This information was then used to calculate body weight gain, and FCR. For deaths during the middle of a weighing period, the dead animal's weight was recorded, and the gain of the dead bird was counted towards pen gain in figuring feed conversion. Number of dead birds was examined as well. At the end of the experiment, 56 broilers were randomly selected from each treatment ( 2 birds per pen) and blood samples were collected in $5 \mathrm{~mL}$ vacuum tubes (Becton Dickinson Vacutainer System, Franklin Lakes, NJ, USA) and then centrifuged $\left(3,000 \times \mathrm{g}, 15 \mathrm{~min}, 4^{\circ} \mathrm{C}\right)$ within one hour after the collection of the sample to separate the serum. The blood urea nitrogen (BUN), creatinine, and glucose in the serum samples were analyzed with an automatic biochemical analyzer (HITACHI 747, Tokyo, Japan) using colorimetric methods.

After blood collection, total 56 broilers were weighed individually and slaughtered by cervical dislocation. The stomach, breast meat, bursa of Fabricius (Bursa cloacalis), liver, spleen, and abdominal fat were then removed by trained personnel and weighed. The breast muscles were stored at $-20^{\circ} \mathrm{C}$ for the following analysis. Organ weight was expressed as a percentage of BW. The breast muscle Hunter $\mathrm{L}^{*}$ (lightness), $\mathrm{a}^{*}$ (redness), and $\mathrm{b}^{*}$ (yellowness) values were determined using a Minolta CR410 chromameter (Konica Minolta Sensing Inc., Osaka, Japan). Cooking loss was determined using $5 \mathrm{~g}$ of breast meat, which was heat-treated in plastic bags separately in a water bath $\left(100^{\circ} \mathrm{C}\right)$ for $5 \mathrm{~min}$. Samples were cooled at room temperature. Cooking loss was calculated as (sample weight) before cooking - sample weight after cooking)/sample weight before cooking $\times 100$. A piece of breast meat was chilled at $2^{\circ} \mathrm{C}$ for $26 \mathrm{~h}$, duplicate $\mathrm{pH}$ values for each sample were measured using a pH meter (Fisher Scientific, Pittsburgh, PA, USA).

\section{Statistical analysis}

All data were subjected to the statistical analysis as a randomized complete block design using the general linear model procedures of SAS [14], and the cage was used as the experimental unit. Differences among treatment means were determined using the Duncan's multiple range test. Statements of statistical significance were based on $\mathrm{p}<0.05$.

\section{RESULTS AND DISCUSSION}

\section{Test and control on corn and soybean meal}

Only maize and soybean meal were included in the formula as the main raw materials to ensure that the non-GMO diets were applied in this experiment. The GMO qualitative analysis results are presented in Table 1 and 2. Four genes including 35S Promoter, NOS Terminator, DP-098140-6, DAS40278-9 were not detected non-GMO maize. $35 S$ Promoter, NOS Terminator, MON89788, DP305423-1, DO356043-5, MON87701, CV127, MON87708, MON87769, DAS-68416-4 were not detected in non-GMO soybean meal. Those results confirmed that the maize and soybean meal which applied in non-GMO meal were non-GMOs.

\section{Corn and soybean meal analysis}

The results of proximate analysis and amino acid analysis presented in Table 3 were reported as the percentage by weight on an as-is basis. In maize, the crude protein of non-GMO maize was $0.17 \%$ higher than that of GMO maize. Nevertheless, the higher content of Lys, Met, Thr was found in GMO maize. In soybean meal, the crude fiber of non-GMO soybean was $3.02 \%$ higher than that of GMO soymeal meal. A higher content of crude protein was observed in GMO soybean meal as well. Besides, the contents of Lys and Met in GMO soybean were $0.6 \%$ and $0.8 \%$ higher than that in non-GMO soybean, respectively. The development of GMO crops, especially the first generation, enhance insect or herbicide resistance, abiotic stress tolerance. The nutrient compositions of GMO grain are 
Table 4. Basal diet composition (as-fed basis)

\begin{tabular}{|c|c|c|c|c|c|c|}
\hline \multirow{2}{*}{ Items } & \multicolumn{2}{|c|}{ Starter ${ }^{1)}$} & \multicolumn{2}{|c|}{ Grower $^{1)}$} & \multicolumn{2}{|c|}{ Finisher $^{1)}$} \\
\hline & TRT $^{2)}$ & $\mathrm{TRT}^{2)}$ & TRT1 $^{2)}$ & TRT2 $^{2)}$ & TRT1 $^{2)}$ & $\mathrm{TRT}^{2)}$ \\
\hline \multicolumn{7}{|l|}{ Ingredient (\%) } \\
\hline Maize (GMO) & 57.41 & - & 60.29 & - & 62.63 & - \\
\hline SBM (GMO) & 36.65 & - & 33.03 & - & 29.56 & - \\
\hline Maize (Non-GMO) & - & 56.81 & - & 59.67 & - & 62.37 \\
\hline SBM (Non-GMO) & - & 36.70 & - & 33.01 & - & 29.46 \\
\hline Tallow & 1.54 & 1.95 & 2.50 & 2.83 & 3.56 & 3.79 \\
\hline Limestone & 1.70 & 1.75 & 1.62 & 1.66 & 1.74 & 1.77 \\
\hline MDCP & 1.39 & 1.37 & 1.32 & 1.31 & 1.36 & 1.35 \\
\hline Salt & 0.31 & 0.31 & 0.31 & 0.31 & 0.31 & 0.31 \\
\hline DL-methionine (99\%) & 0.36 & 0.42 & 0.32 & 0.38 & 0.36 & 0.42 \\
\hline L-lysine-HCl (98.5\%) & 0.23 & 0.26 & 0.22 & 0.25 & 0.14 & 0.17 \\
\hline L-threonine $(98.5 \%)$ & 0.11 & 0.13 & 0.09 & 0.11 & 0.04 & 0.06 \\
\hline Choline (60\%) & 0.10 & 0.10 & 0.10 & 0.10 & 0.10 & 0.10 \\
\hline Vitamin premix ${ }^{3)}$ & 0.10 & 0.10 & 0.10 & 0.10 & 0.10 & 0.10 \\
\hline Mineral premix ${ }^{4)}$ & 0.10 & 0.10 & 0.10 & 0.10 & 0.10 & 0.10 \\
\hline Total & 100.0 & 100.0 & 100.0 & 100.0 & 100.0 & 100.0 \\
\hline \multicolumn{7}{|c|}{ Calculated composition (\%) } \\
\hline Crude protein & 22.00 & 22.00 & 20.50 & 20.50 & 19.00 & 19.00 \\
\hline Crude fiber & 2.24 & 3.77 & 2.16 & 3.61 & 2.09 & 3.44 \\
\hline Crude fat & 4.35 & 4.29 & 5.35 & 5.21 & 6.45 & 6.21 \\
\hline Ash & 6.23 & 6.35 & 5.91 & 6.00 & 5.78 & 5.94 \\
\hline ME (kcal/kg) & 3,000 & 3,000 & 3,100 & 3,100 & 3,200 & 3,200 \\
\hline $\mathrm{Ca}$ & 0.95 & 0.95 & 0.90 & 0.90 & 0.90 & 0.90 \\
\hline$A P$ & 0.4 & 0.4 & 0.38 & 0.38 & 0.49 & 0.50 \\
\hline SID-Lys & 1.25 & 1.25 & 1.15 & 1.15 & 1.00 & 1.00 \\
\hline SID-TSAA & 0.95 & 0.95 & 0.87 & 0.87 & 0.76 & 0.76 \\
\hline SID-Thr & 0.85 & 0.85 & 0.78 & 0.78 & 0.68 & 0.68 \\
\hline
\end{tabular}

GMO, genetically modified organism; SBM, soybean meal; MDCP, mono-calcium and di-calcium phosphate; ME, metabolic energy; AP, available phosphorus; SID, standard ileal digestibility; TSAA, total sulfur amino acid.

1) Starter diets, provided during weeks 0 to 1; grower diets, provided during weeks 2 to 5 .

${ }^{2)}$ TRT1, GMO corn-SBM diet; TRT2, non-GMO corn-SBM diet. Each treatment had 28 replicate pens of 15 broilers in each pen.

3) Provided per $\mathrm{kg}$ of diet: 15,000 IU of vitamin $A, 3,750 \mathrm{IU}$ of vitamin $D_{3}, 37.5 \mathrm{mg}$ of vitamin $\mathrm{E}, 2.55 \mathrm{mg}$ of vitamin $\mathrm{K}_{3}, 3 \mathrm{mg}$ of thiamin, $7.5 \mathrm{mg}$ of riboflavin, $4.5 \mathrm{mg}$ of vitamin $B_{6}, 24 \mu \mathrm{g}$ of vitamin $B_{12}, 51 \mathrm{mg}$ of niacin, $1.5 \mathrm{mg}$ of folic acid, $0.2 \mathrm{mg}$ of biotin and $13.5 \mathrm{mg}$ of pantothenic acid.

4) Provided per kg of diet: $37.5 \mathrm{mg} \mathrm{Zn} \mathrm{(as} \mathrm{ZnSO}_{4}$ ), $37.5 \mathrm{mg}$ of $\mathrm{Mn}_{\left(\mathrm{MnO}_{2}\right)}$, $37.5 \mathrm{mg}$ of Fe (as FeSO $\mathrm{F}_{4} \cdot 7 \mathrm{H}_{2} \mathrm{O}$ ), $3.75 \mathrm{mg}$ of Cu (as CuSO $\mathrm{H}_{4} \cdot 5 \mathrm{H}_{2} \mathrm{O}$ ), $0.83 \mathrm{mg}$ of I (as KI), and $0.23 \mathrm{mg}$ of $\mathrm{Se}\left(\mathrm{as} \mathrm{Na}_{2} \mathrm{SeO}_{3} \cdot 5 \mathrm{H}_{2} \mathrm{O}\right)$.

better than that of non-GMO materials. Probably due to fewer challenging factors (insect, herbicide or abiotic stress) affecting the accumulation of nutrients in the growth process. Besides, Rayan et al [15] reported that there were some statistical differences between the GMO corn samples and non-GMO control in some biochemical components. But he believed that those results were unlikely to be biologically significant, since they were well within the range of literature values.

\section{Growth performance and nutrient digestibility}

The results of growth performance and nutrient digestibility are presented in Table 5 and 6 . The FI and FCR were greater $(\mathrm{p}<0.05)$ in broilers provided with non-GMO diet feed than that in the GMO group from day 17 to 32 . A decrease FCR was observed when birds were fed with the GMO diet through the whole experiment $(\mathrm{p}<0.05)$. In 1997, A program was started to assess GMO including Bt-maize, Pat-maize, Pat-sugar beets and Gt-soybeans, which tried to determine an effective system to assess GMO in feed stuffs from the view of nutrition. In 2001, the series of experiments reported by Flachowsky et al [16] had been published by Aulrich et al [17,18], Bohme et al [19], Daenicke et al [20,21], and Halle et al [22]. Results of all the experiments did not show any significant difference in growth performance and nutrient digestibility between GMO diet and non-GMO diet. The latest article on non-GMO Feed stuff in broilers was published in 2010 by Świątkiewicz et al [23], which revealed that no statistical difference was observed in any of the performance parameters across dietary treatments. Only two articles showed some improvements in growth performances when birds were fed the GMO-diet, one of the two papers published in 1998 showed the birds receiving GMO-corn diets exhibited improved adjusted feed conver- 
Table 5. Effect of GMO and non-GMO corn-SBM diets on growth performance of broilers

\begin{tabular}{lccc}
\hline Items & TRT1 $^{1)}$ & TRT2 $^{1)}$ & SEM \\
\hline Initial BW (g) & 43 & 43 & 0 \\
d 7 BW & 135 & 133 & 1 \\
d 17 BW & 573 & 576 & 5 \\
d 32 BW & 1,706 & 1,679 & 14 \\
d 1-7 & & & \\
BWG (g) & 92 & 90 & 1 \\
FI (g) & 106 & 108 & 1 \\
FCR & 1.154 & 1.196 & 0.015 \\
d 7-17 & & & \\
BWG (g) & 438 & 429 & 5 \\
FI (g) & 611 & 595 & 6 \\
FCR & 1.398 & 1.390 & 0.129 \\
d 17-32 & & & \\
BWG (g) & 1,134 & 1,117 & 14 \\
FI (g) & $1,724^{\mathrm{b}}$ & $1,762^{\mathrm{a}}$ & 11 \\
FCR & $1.524^{\mathrm{b}}$ & $1.579^{\mathrm{a}}$ & 0.014 \\
Overall & & & \\
BWG (g) & 1,663 & 1,636 & 13 \\
FI (g) & 2,440 & 2,464 & 12 \\
FCR & $1.468^{\mathrm{b}}$ & $1.507^{\mathrm{a}}$ & 0.009 \\
Mortality rate (\%) & 1.743 & 1.966 & 0.36 \\
\hline GWO genetical modfied & & \\
\hline
\end{tabular}

GMO, genetically modified organism; SBM, soybean meal; SEM, standard error of means; BW, body weight; BWG, body weight; FI, feed intake; FCR, feed conversion rate.

1) TRT1, GMO corn-SBM diet; TRT2, non-GMO corn-SBM diet. Each treatment had 28 replicate pens of 15 broilers in each pen.

${ }_{a, b}$ Means in the same row with different superscripts differ $(p<0.05)$.

sion ratios at 28 and 38 days of age. The author considered that the improved feed conversion ratios cannot necessarily be attributed to the corn source, but these data did show an absence of any deleterious effects associated with the diets made from GMO when compared to diets made from non-GMO corn [24]. However, our study found that the GMO-diet exhibited a better growth performance of FCR than non-GMO diet. Chicks fed non-GMO diet have higher FCR than those fed GMO diet which was attributed to the higher food intakes. The first reason for these differences may be a higher apparent metabolic energy value assumed for diet formulation. The metabolic energy (ME) value of the experimental diets are calculated based on CVB Table Booklet Feeding of poultry recommendation [25]. It is not clear whether standard nonGMO maize or soybean meal supplied the similar ME as much

Table 6. Effect of GMO and non-GMO corn-SBM diets on nutrient digestibility of broilers

\begin{tabular}{llll}
\hline Items (\%) & TRT1 $^{1)}$ & TRT2 $^{1)}$ & SEM \\
\hline Dry matter & 73.92 & 74.13 & 0.69 \\
Nitrogen & 71.11 & 72.10 & 0.61 \\
\hline
\end{tabular}

SEM, standard error of means; SBM, soybean meal.

1) TRT1, GMO-SBM diets; TRT2, non-GMO corn-SBM diets. Each treatment had 28 replicate pens of 15 broilers in each pen. as GMO maize for diet. During age of $\mathrm{d} 17$ to $\mathrm{d}$ 32, broilers are in faster growth than that at age of 2 weeks. Goliomytis [26] documented the growth rate from 3 weeks to 6 weeks of BW, breast weight and leg weight were greater than that in first 2 weeks in broilers. Therefore, the protein and amino acids could be crucial one of all elements. The second reason may be different amino acids compositions or protein characteristics between GMO and non-GMO diet. The lower content of first 3 limiting essential amino acids occur in non-GMO feed stuff, the more crystalline amino acids have to be used in a non-GMO diet. But, the nutritional value of protein in animal feed may be related not only to amino acid content and composition, but also to the different resource of protein characteristics. Differences in physical and chemical properties of protein resource also affect the release dynamics of amino acids in the digestive tract of animals. The GMO varieties of plants which were called second-generation crops have traits to enhance nutritional properties [27]. Furthermore, the branched-chain amino acids which plays several critical roles in metabolism homeostasis and cell functions including immunity, survival and growth, energy homeostasis, and protein and lipid metabolism regulation [28] were not calculated in diet. Our amino acid analysis showed the quantity of branched-chain amino acids in non-GMO grain were around 1.15 times as much as that in non-GMO grain. Therefore, the relatively lower content of branched-chain amino acids in non-GMO diets might be another reason for the influence.

\section{Blood profile, meat quality, and organ weight}

No significant impact on blood profile, meat quality, organ weight was found in response to the two treatments throughout the experimental period (Tables 7,8$)(\mathrm{p}>0.05)$. Serum creatinine (a blood measurement) is an important indicator of renal health because it is an easily-measured by-product of muscle metabolism that is excreted unchanged by the kidneys. Plasma or BUN concentration may be useful as an indicator of protein status within a group of animals as well as nitrogen utilization and could help to fine-tune diets or identify problems with a feeding program [29]. Those results might demonstrate that the metabolism of protein and amino acids are not affected in the birds fed non-GMO and GMO diets. Consistent with our research, almost all previous published

Table 7. Effect of GMO and non-GMO corn-SBM diets on blood profile of broilers

\begin{tabular}{lccc}
\hline Items (mg/dL) & TRT1 $^{1)}$ & TRT2 $^{1)}$ & SEM \\
\hline Blood urea nitrogen & 2.75 & 2.25 & 0.46 \\
Blood creatinine & 0.16 & 0.18 & 0.01 \\
Blood glucose & 225.00 & 228.75 & 0.95 \\
\hline
\end{tabular}

SEM, standard error of means; SBM, soybean meal.

1) TRT1, GMO corn-SBM diets; TRT2, non-GMO corn-SBM diets. Each treatment had 28 replicate pens of 15 broilers in each pen. 
Table 8. Effect of GMO and non-GMO corn-SBM diets on meat quality and organ weigh of broilers

\begin{tabular}{|c|c|c|c|}
\hline Items & TRT1 $^{1)}$ & TRT2 $^{1)}$ & SEM \\
\hline $\mathrm{pH}$ value & 5.55 & 5.50 & 0.06 \\
\hline \multicolumn{4}{|l|}{ Breast muscle color } \\
\hline Lightness (L*) & 53.38 & 53.97 & 0.66 \\
\hline Redness $\left(a^{*}\right)$ & 10.28 & 10.29 & 0.42 \\
\hline Yellowness $\left(b^{*}\right)$ & 9.13 & 9.14 & 0.23 \\
\hline Cooking loss & 34.65 & 34.30 & 0.16 \\
\hline WHC (\%) & 51.32 & 52.74 & 1.69 \\
\hline \multicolumn{4}{|l|}{ Drip loss (\%) } \\
\hline d 1 & 2.87 & 2.75 & 0.20 \\
\hline d 3 & 5.58 & 5.51 & 0.05 \\
\hline d 5 & 8.69 & 8.69 & 0.03 \\
\hline$d 7$ & 10.78 & 10.70 & 0.13 \\
\hline \multicolumn{4}{|c|}{ Relative organ weight (\%) } \\
\hline Breast muscle & 18.51 & 18.54 & 0.11 \\
\hline Liver & 2.51 & 2.54 & 0.09 \\
\hline Bursa cloacalis & 0.12 & 0.13 & 0.01 \\
\hline Abdominal fat & 3.42 & 3.54 & 0.16 \\
\hline Spleen & 0.10 & 0.11 & 0.01 \\
\hline Gizzard & 1.13 & 1.12 & 0.01 \\
\hline
\end{tabular}

SEM, standard error of means; WHC, water holding capacity; SBM, soybean meal. 1) TRT1, GMO corn-SBM diets; TRT2, non-GMO corn-SBM diets. Each treatment had 28 replicate pens of 15 broilers in each pen.

$a, b$ Means in the same row with different superscripts differ $(p<0.05)$.

papers demonstrated that no statistic difference in carcass and organ weight was found between GMO and non-GMO feed. For example, the study of Tatlor et al [30] showed that no difference in carcass characteristics was present between birds were fed either GMO-maize or non-GMO maize.

\section{CONCLUSION}

In conclusion, a non-GMO maize-soybean basal diet had no adverse effects on blood profile, carcass characteristic and meat quality in broilers. However, growth performance was reduced when the birds were fed a non-GMO diet. Further experiments are required to determine the reason for this result.

\section{CONFLICT OF INTEREST}

We certify that there is no conflict of interest with any financial organization regarding the material discussed in the manuscript. Ao X is an employee of Kemin Industries (Zhuhai) Co., Ltd.

\section{ACKNOWLEDGMENTS}

This work was supported by the department of Department of Animal Resource \& Science, Dankook University. Sincerely appreciates the Daehan Feed Mill Company raw materials support and Kemin Industries technical support.

\section{REFERENCES}

1. Hammond BG, Vicini JL, Hartnell GF, et al. The feeding value of soybeans fed to rats, chickens, catfish and dairy cattle is not altered by genetic incorporation of glyphosate tolerance. J Nutr 1996;126:717-27.

2. FAO/WHO. Strategies for assessing the safety of foods processed by biotechnology. Report of a joint FAO/WHO consultation. Geneva, Switzerland: WHO; 1991.

3. FAO/WHO. Biotechnology and food safety. Report of a joint FAO/WHO consultation. FAO, Food and nutrition. Geneva, Switzerland: WHO; $1996.61 \mathrm{p}$.

4. FAO/WHO. Safety aspects of genetically modified foods of plant origin. Report of a joint FAO/WHO consultation. Geneva, Switzerland: WHO; 2000.

5. US EPA. Bt plant-pesticides risks and benefits assessments: Insect resistance management. SAP Report No. 2000-07a, 2001.

6. US FDA. Statement of policy: Foods derived from new plant varieties. Federal Register 1992. 57:22984-3005.

7. Wagner W, Kronberg N, Gaskell G, et al. Nature in disorder: the troubled public of biotechnology. In: Gaskell G, Bauer M, editors. Biotechnology 1996-2000: the years of controversy. London UK: The National Museum of Science and Industry; 2001. pp. 80-95.

8. Lassen J, Madsen KH, Sandøe, P. Ethics and genetic engineering - lessons to be learned from GM foods. Bioprocess Biosyst Eng 2002;24:263-71.

9. Miles S, Frewer LJ. QPCR GMO food work package 6: Socioeconomic impact of GMO regulation and GMO detection. Report to the European Commission. Norwich, CT, USA: Institute of Food Research; 2001

10. Brake J, Faust MA, Stein J. Evaluation of transgenic event bt11 hybrid corn in broiler chickens. Poult Sci 2003;82:551-9.

11. Kan CA, Hartnell GF. Evaluation of broiler performance when fed insect-protected, control, or commercial varieties of dehull soybean meal. Poult Sci 2004;83:2029-38.

12.AOAC. Official methods of analysis. 17th ed. Gaithersburg, MD, USA: AOAC International; 2000.

13. Nutrient requirement of poultry. NRC. Washington, DC, USA: National Academy Press; 1994.

14.SAS Institute. SAS user's guide: statistics. Version 7.0 ed. Cary, NC, USA: SAS Institute Inc; 1998.

15. Rayan AM, Abbott LC. Compositional analysis of genetically modified corn events (NK603, MON88017 ×MON810 and MON89034×MON88017) compared to conventional corn. Food Chem 2015;176:99-105.

16. Flachowsky G. Aulrich K. Nutritional assessment of feeds from genetically modified organism. J Anim Feed Sci 2001;10(Suppl 1): 181-94.

17. Aulrich K, Halle I, Flachowsky G. Effect of genetically modified 
Bt-hybrids mazie on digestibility in laying hens. HO.VDLUFAConference, Giessen, Germany; 1998. pp. 465-8.

18. Aulrich K, Bohme H, Daenicke R, Halle I, Flachowsky G. Genetically modified feeds in animal nutrition 1st communication: Bacillus thuringiensis (Bt) corn in poultry, pig and ruminant nutrition. Arch Tierernahr 2001;54:183-95.

19. Bohme H, Aulrich K, Daenicke R, Flachowsky G. Genetically modified feeds in animal nutrition. 2nd communication: glufosinate tolerant sugar beets (roots and silage) and maize grains for ruminants and pigs. Arch Tierernahr 2001;54:197207

20.Daenicke R, Aulrich K, Flachowsky G. GMOs-corn in the diet. Mais 1999;27:135-7.

21.Daenicke R, Aulrich K, Flachowsky G. Impact of transgenic and isogenic hybrids maize and Rubenblatt on the digestibility and gene silage in mutton. VDLUFA Kongressband 2000, 112. VDLUFA-Kongress, 2000; 141 (Abstr.)

22. Halle I, Aulrich K, Flachowsky G. Use of cesar corn kernels and genetically modified Bt hybrids in broilers. Proceedings of 5 Meeting, Pigs and Poultry Nutrition; Wittenberg, Germay; 1999. pp. 265-71.

23. Świątkiewicz S, Twardowska M, Markowski J, Mazur M, Sieradzki Z, Kwiatek K. Nutritional efficiency of genetically modified, insect resistant corn (MON810) and glyphosate tolerant soybean meal (Roundup Ready) for broilers. Bull Vet Inst Pulawy 2010;54:43-8.
24. Brake J, Vlachos D. Evaluation of transgenic event 176 "Bt" corn in broiler chickens. Poult Sci 1998;77:648-65.

25.CVB. Veevoedertabel (feeding value of feed ingredients) Lelystad, The Netherlands: Central Veevoeder Bureau; 2007.

26. Goliomytis M, Panopoulou E, Rodgdakis E. Growth curves for body weight and major component parts, feed consumption, and mortality of male broiler chickens raised to maturity. Poult Sci 2003;82:1061-8.

27. Denbow DM, Grabau EA, Lacy GH, Kornegay ET, Russel DR, Umbeck PF. Soybeans transformed with a fungal phytase gene improve phosphorus availability for broilers. Poult Sci 1998; 77:878-81.

28. Bai J, Greene E, Li WF, Kidd MT, Dridil S. Branched-chain amino acids modulate the expression of hepatic fatty acid metabolismrelated genes in female broiler chickens. Mol Nutr Food Res 2015;59:1171-81.

29. Whang KY, Kim SW, Donovan SM, Mckeith FK, Easter RA. Effects of protein deprivation on subsequent growth performance, gain of body components, and protein requirements in growing pigs. J Anim Sci 2003;81:705-16.

30. Taylor ML, Hartnell G, Nemeth M. Comparison of broiler performance when fed diets containing corn grain with insectprotected (corn rootworm and european corn borer) and herbicide-tolerant (glyphosate) traits, control corn, or commercial reference corn—revisited. Poult Sci 2005;84:1893-9. 